\title{
Regulating stakeholder pensions
}

Received: 10th March, 2000

\section{John Hayes CBE,}

a solicitor by training, was appointed Chairman of Opra in April 1996 and took up the appointment on a full-time basis in June 1996. He was formerly Secretary General of the Law Society for nine years.

\begin{abstract}
This paper aims to describe the way in which the Government's new pension product, the stakeholder pension, will be regulated. It looks at its history and how different aspects will be regulated, according to whether the scheme is trust-based or has been approved under the alternative governance structure. The paper describes the registration requirements and explains, principally from Opra's perspective, how the new regime will be enforced. The paper outlines the requirements on employers to nominate a stakeholder pension scheme, and to provide a payroll facility if required.
\end{abstract}

Keywords: Opra; stakeholder pensions; joined up regulation; Welfare and Pensions Reform Act 1999; Finance Bill 2000; alternative governance; employee access

\section{Introduction}

Stakeholder pensions, a flagship New Labour project, are expected to become a reality in April 2001. It is no secret that the Government wants them in place before the next general election. Whether this is achieved may no longer be a factor of political will, but of technological capacity, including the ability of NIRS2, now the Inland Revenue computer system, to perform critical tasks relating to contracting out of the new second state pension arrangements. Now that the Inland Revenue has taken over the DSS's Contributions Agency, it is worth noting that it has two regulatory roles, tax approval and policing rules about contracting out.

Against this background, it is obviously a mistake to believe that the only potential area for the multiple regulation of stakeholder pensions is to be found in the dual roles of the Financial Services Authority (FSA) and the Occupational Pensions Regulatory
Authority (Opra). Some commentators, including some providers and politicians, look upon the proposals with some alarm, tempered for some by the conviction that this conundrum will be resolved ultimately by the merger of FSA and Opra. Similar reservations are expressed about the involvement of the Financial Services Ombudsman and the Pensions Ombudsman; a recipe, the critics say, for confusion, complexity, inconsistencies and, worst of all, unchecked abuses.

Opra, however, is determined to do its best to practise what the Government might describe as 'joined up' regulation. Before turning to this aspect, it may be worth reflecting on the evolution of the stakeholder concept.

\section{Stakeholder pensions background}

Before the last election, John Denham MP, then the junior opposition 
spokesman, produced papers which were later subsumed in the Labour Party's election manifesto proposing the introduction of stakeholder pensions. In essence, they were to meet the needs of those unable to participate in occupational pension schemes, either because their employer did not provide one or because, for one reason or another, they were not in continuous employment. Labour was also determined to learn from the personal pensions debacle they considered had been caused by the Tory administration and the insurance industry.

Once in Government, it was soon realised that the task was more complex and divisive than had been appreciated in opposition. Frank Field MP was brought in as Minister of State to think the unthinkable, working alongside John Denham as the junior minister, while a formidable Treasury team took a more than passing interest on the development of the stakeholder project. Notably Helen Liddell MP, at the Treasury, showed considerable concern with the progress made by the insurance industry in clearing up the pensions misselling mess. Gordon Brown, the Chancellor of Exchequer, within a month of the general election, announced the creation of the Financial Services Authority to take over from the Securities and Investment Board, the self-regulating organisations and the recognised professional bodies, in the regulation of financial services and products. The Chancellor showed he was prepared to take on the occupational pension scheme leaders by introducing significant changes to some of the tax advantages enjoyed by them.

Against this background, the process of issuing firm proposals for stakeholder pensions and for reforming the State Earnings Related Pension Scheme (SERPS) was painfully slow. When the
Green Paper was issued, Frank Field had already returned to the back benches and with it, some of the critics said, a truly radical approach evaporated. Introducing higher levels of compulsion in saving for retirement was rejected, and SERPS, while not dropped altogether, was given a substantial makeover through the proposed second state pension, now S2P.

The DSS, it appeared, backed a trust-based stakeholder pension, modelled on the occupational pension scheme. A trust basis, it was argued, was essential to provide that a scheme was organised in the best interests of the members, especially the target audience for stakeholder pensions, the moderately paid earning between $£, 9,500-£ 20,000$ a year. In parallel the Treasury, having launched the ISA concept for savings, was determined to make an equally significant contribution to pensions policy. This led to the promotion of the pooled pension investment (ppi) vehicle previously labelled, at least informally, as a LISA (long-term investment and savings arrangements). It was heavily backed by AUTIF (Association of Unit Trusts and Investment Funds) as a more transparent investment product. The ppi was said by its protagonists to be more flexible and attractive in a European context than the traditional trust-based occupational pension scheme. But it was an investment vehicle rather than a pension scheme in its own right - a useful component of many pensions portfolios. As part of an alternative package it could appeal to those unattracted by the collectivist or affinitybased, stakeholder trust scheme. It was said to be particularly attractive to younger, more mobile workers, who, according at least to some industry folklore and elements in the chattering classes, were short-changed by traditional occupational final salary schemes when they moved jobs. 
Thus, the Government proposed an alternative to trust-based stakeholder schemes, subject like them to standards relating to charges, minimum contributions and transferability.

\section{Problems of regulation}

The Welfare and Pensions Reform Act 1999 thus created the framework for both trust and non-trust, or 'contract', stakeholder schemes. The Finance Bill 2000 will deal with the tax aspects, especially the innovative proposals for stakeholder pension schemes to be held in parallel with defined contribution personal pensions and occupational pensions.

Trust and contract stakeholder schemes will need to be registered with Opra and approved by the Pension Schemes Office of the Inland Revenue. They will need to show that they meet certain conditions relating to:

- being established under trust or the other approved governance structure

- being money purchase arrangements

- limits on charges

- compliance with requirements about disclosing information about the scheme and the member's entitlement

- allowing members to make minimum contributions not less than $\mathcal{f}^{20}$ and how often they can change their instructions about the amount of such payments

- approval of the acceptance of transfer payments.

It will be seen that trustees and managers who fail to comply with the registration standards at any time will be liable for fines of up to $\mathcal{E}^{50,000}$ imposed by Opra. If they are trustees, they could be banned from office. The managers of a contract-based scheme could also suffer fines at the hands of Opra.
For a trust-based scheme there does not appear to be any fit or proper person test, nor a power to block a scheme that appears to meet the relevant conditions. Stakeholder schemes will not all have the benefit of bringing together people who share some common bond, such as working for the same employer, so the scope for people doing disreputable things which go unnoticed by others is increased. Opra has come across cases of spurious occupational schemes fronted by people of dubious background, some of whom were automatically disqualified from acting as a pension fund trustee because of a criminal conviction for dishonesty, bankruptcy, or a Companies Act disqualification. Opra will be asking trustees (or directors of corporate trustees) to complete an individual questionnaire in order to verify that they are not ineligible to act, so that at the very least they will be liable to be prosecuted for a criminal offence if they fail to disclose one of these factors. Becoming a manager authorised by the Financial Services Authority will be a far more onerous hurdle.

Opra will have to make the best use of its involvement in various financial intelligence and surveillance networks. It will inevitably lead to looking at complaints relating to schemes whose trustees do not have readily recognisable and satisfactory track records, being examined at times with a care and depth which the initial complaint might not obviously merit.

Complaints as well as reports in the media will be important drivers in monitoring adherence to registration conditions. Stakeholder schemes must have a scheme auditor. There is no obligation for auditors to whistleblow, set out in the primary legislation, unless the scheme is trust based. Unlike final salary occupational schemes, there will normally be no scheme actuary. It is likely, 
especially in the early days, that Opra will want to encourage trustees and managers to be open about shortcomings in return for lenience over inadvertant isolated breaches, where remedial action is taken promptly and no one is damaged by the failure.

Opra will not instinctively move into sanction mode. However, the leniency shown to occupational schemes, with predominantly lay unpaid trustees, should not be expected to be slavishly replicated when dealing with providers who are in it for money.

It will be the FSA who will monitor the sales process, but complaints that touch on the registration conditions will be passed to Opra. It will use statutory gateways to ensure that investigations are carried out without needless duplication, or damaging the work of others in bringing to justice defaulters and protecting members' interests. Arrangements between the regulatory forces need to be strongest at the working level rather than rest on little more than a high-sounding memorandum, or an excuse for extensive meetings in exotic locations.

The regulation of disclosure of information and other requirements similar to those which already apply to occupational schemes, and which will also be applied to contract-based stakeholder schemes, will fall to Opra to the extent that they are registration conditions. Pre-sale promotional and marketing material to prospective members will be subject to FSA rules. It is known that late payment of contributions by employers to stakeholder schemes will be enforced by Opra, with important new obligations on the managers or trustees to tell Opra if payments are late. This obligation will extend to the providers of any personal pension (including a group personal pension) to whom payments are made by an employer on his own or his employees' behalf.

The adequacy of these arrangements as reflected in insurers' administration systems has been the subject of discussion between Opra, insurers and the FSA.

This is because an unscrupulous employer is unlikely to tell either Opra, or his workers, if payments have been missed. Waiting for the audit to reveal a problem is not enough. We are told that many insurers lack the systems to identify against particular employer clients, the personal pensions they have opened in respect of individual employees of that employer. Such weaknesses will not do in the new stakeholder environment or allow group personal pension schemes to adapt to the modern regulatory requirement.

Employees who have a group personal pension scheme to which they contribute at least 3 per cent of payroll will be exempt from having to provide access to a stakeholder scheme, provided there is no penalty when employees leave the job and want to take their pension entitlement with them. But it looks as if up to 500,000 employers could be obliged to provide access to a stakeholder scheme unless all their employees can join their occupational scheme within a year. Opra will be empowered to fine employers up to $£ 50,000$ if they fail to do so, but it is clear that, above all, this is a massive educational and administrative exercise rather than primarily, or initially, a penalty imposing programme.

The FSA has been anxious to stress that employers will not require to be authorised under financial services legislation merely because they commend the employee to join the scheme they have chosen, unless they attempt to compare its merits with those of other specific investments. The Government accepted an amendment to the Welfare 
Reform and Pensions Bill so that employers should not be liable for the performance of a scheme they had chosen.

\section{Conclusion}

The Minister of State now in charge of the stakeholder project, Jeff Rooker, has indicated that the success of stakeholders should be judged in three to five years after stakeholders become a reality, by whether 50 per cent of the target audience, people earning between $\mathcal{E}^{9}, 500$ and $\mathcal{E} 20,000$ previously without any second pension, are then signed up for stakeholder membership. This is ambitious and is probably not the measure the pensions industry will be using. Profit is likely to come from the higher earners enjoying stakeholder provision alongside occupational or other money purchase provisions. Occupational schemes may react by changing their rules so that people previously excluded will be admitted. Their continued omission would have led employers to be required to offer them access to a stakeholder scheme.

Another important side effect of the stakeholder project will be seen as a reduction in charges, with serious implications for sales forces and IFAs. The need to invest in sophisticated computer systems at the same time as receiving less income from the sale of each pension will be a further driver in the consolidation of the insurance market. However, new providers especially from the USA with most of the necessary information technology investment already in place, may choose this as a good moment to enter the market by purchasing existing providers who have good access to employers and other buyers, but who lack the technical backup to exploit the stakeholder market.

So while the detail of the regulation of stakeholder pensions is far from complete, the impact of the stakeholder concept will stretch much further than the people for whom it is intended. 